\title{
10
}

\section{Solomon Islands' Foreign Policy Dilemma and the Switch from Taiwan to China}

\author{
Transform Aqorau
}

\section{Introduction}

In September 2019, Solomon Islands severed its diplomatic relations with the Republic of China (Taiwan) and recognised the People's Republic of China (China). This followed months of public discussions about the Solomon Islands Government's proposal to 'switch', illustrating the uncertain nature of its relationship with Taiwan, which was established in 1983. However, this is not unique to Solomon Islands; it characterises Taiwan's diplomatic relations around the world. As China's global influence grows, Beijing has been able to persuade a number of countries to abandon Taiwan. Central to this are Beijing's One China policy and its claim that Taiwan is a renegade province. In 2017, Panama severed relations with Taiwan, followed by El Salvador, the Dominican Republic and Burkina Faso in 2018. In September 2019, Solomon Islands and Kiribati switched relations from Taiwan to China. This leaves only 14 countries, plus the Holy See, that continue to have diplomatic relations with Taiwan, including four Pacific Island countries: Palau, the Republic of the Marshall Islands (RMI), Tuvalu and Nauru. 
This chapter examines the nature of the diplomatic relationship between Solomon Islands and Taiwan and discusses the factors underlying the Solomon Islands Government's decision to sever that relationship. It asserts that the decision to switch was influenced largely by the increase in trade between China and Solomon Islands over the past two decades. It also discusses how the relationship has been influenced by a new wave of Chinese migrants who dominate the retail sector in Honiara and, increasingly, the provinces. It also highlights how these new Chinese migrants have had a negative influence on the quality of governance in Solomon Islands. It then discusses issues the Solomon Islands Government should be cognisant of in its new relationship with China. The government should be conscious of the fact that it does not currently have the resources, moral fortitude and knowledge capital to effectively manage this relationship, a relationship that will be characterised by Beijing's assertive influence, an increase in the number of Chinese companies in the country, especially with investments in natural resource-extractive industries and the potential for a continuing increase in the Chinese migrant population and their dominance in retail businesses. The chapter proposes that the Solomon Islands Government should work on building knowledge capital about the Chinese state, corporations and peoples. This will enable it to best manage the relationship and ensure that there is mutual benefit between the two countries. The chapter concludes by reflecting on the future implications of Solomon Islands' diplomatic relationship with China.

The underlying questions of this chapter are: What were the factors that influenced Solomon Islands' relationship with Taiwan? What were the rationales for the switch to China? What are the implications of the switch for Solomon Islands? What can and should Solomon Islands do to ensure that it benefits from its relationship with China?

\section{Taiwan or China? Solomon Islands' foreign policy dilemma}

Following independence in 1978, the Solomon Islands Government contemplated establishing diplomatic relations with China. In April 1982, the then minister of foreign affairs and international trade Ezekiel Alebua visited China for talks that were expected to lead to the establishment of diplomatic relations. On his return, Alebua said that 'a good diplomatic 
foundation has been laid for future sound diplomatic and trade relations between both countries' (Solomon Islands Government Monthly Magazine 1982). But the Solomon Islands Government was at the same time warming up to Taiwan, sending officials to Taipei. So, the battle between China and Taiwan for diplomatic relations with Solomon Islands started at the dawn of independence. In 1983, Honiara established diplomatic relations with Taiwan, beginning a 36-year relationship (Kabutaulaka 2010).

At various times in the past three decades, prominent Solomon Islanders have flirted with the idea of abandoning diplomatic relations with Taiwan and switching to China. As recently as 24 January 2019, for example, the Democratic Alliance Party (DAP) of then prime minister Ricky Houenipwela announced at their convention that they would review Solomon Islands' diplomatic relations with Taiwan if they were reelected to government in the April 2019 national general elections. Prime Minister Houenipwela noted: 'The possibility of actively pursu[ing] opportunities on South-South cooperation ${ }^{1}$ and partnership is one of the DAP international affairs policy' (Fanasia 2019). These sentiments cannot be underestimated, as they came from the party of the incumbent prime minister whose government had courted and enjoyed a long relationship with Taiwan. As far as I am aware, this was the first time that any political party had made the issue of the country's diplomatic relationship with Taiwan part of its political platform. It was also a reflection of China's growing importance to Solomon Islands.

By the eve of the April 2019 elections, Solomon Islands was at a diplomatic crossroads. The reasons that had led other countries to sever relations with Taiwan since its pro-independence Democratic Progressive Party (DPP) won the presidential elections in 2016 could not be ignored. Since the end of the DPP's informal diplomatic truce with Taiwan's other major political party - the nationalist Kuomintang Party—even more countries have left Taiwan for China. This partly reflects these countries' desire to go along with the global trend, wherein the majority of countries recognise China, an economic and political superpower that cannot be ignored.

This trend also impacted Solomon Islands. Following the April 2019 elections, Manasseh Sogavare was elected prime minister and formed the Democratic Coalition Government for Advancement (DCGA). In its

1 China regards itself as a developing country and hence frames its development assistance as South-South cooperation rather than aid, which implicitly requires a donor and recipient. 
First 100-Days Policy Framework, the DCGA stated that it would review its development partners and engage in a 'comprehensive assessment on the China question' (DCGA 2019:7). In the months that followed, the DCGA Government unveiled its policy to switch diplomatic relations to China and began an assertive campaign to implement it. A bipartisan task force was established to 'assess the gains of the current bilateral relations with ROC and to provide a strategy for the government to counter any positive and negative impacts of a potential switch' (Solomon Islands Government 2019:5). The task force visited Vanuatu, Fiji, Tonga, Samoa and China, then wrote and submitted its report to caucus. At the same time, the Solomon Islands parliamentary Foreign Relations Committee was tasked to:

initiate this inquiry to examine, observe and make recommendations on the question of severing existing ties with the Republic of China (Taiwan) and the conduct of government's foreign policy in light of the same (National Parliament of Solomon Islands Foreign Relations Committee 2019:15).

The following discusses in some detail the debates surrounding the switch. Even the contemplation of a switch was a major blow to Taiwan, especially given the fact that Solomon Islands was the largest, and perhaps most important, of the six Pacific Island countries that had diplomatic relations with Taiwan at the time. It was also one of three Pacific nations, along with Tuvalu and Palau, that had never had diplomatic relations with China. The other three-Marshall Islands, Nauru and Kiribati-previously had diplomatic relations with China, but later switched to Taiwan. Nauru provides an interesting example of a country that switches to whoever writes it a cheque. It initially had diplomatic relations with Taiwan, switched to China in 2002, then reestablished ties with Taiwan in 2005 when it discovered that China was not going to subsidise their national airline, which had been declared bankrupt by the courts in Australia. Taiwan's method of keeping Nauru members of parliament in line was simple. According to a 2010 report published in The Australian:

The Taiwanese money man comes once a month. An official from the local embassy, he doles out $\$$ US4000 in Australian currency to every one of Nauru's 18 members of parliament (Maley 2010).

In keeping with this practice of chequebook diplomacy, Nauru was one of the few nations to recognise the Russian proxy states of Abkhazia and South Ossetia (Wyeth 2017). 
In the past decade, there has been renewed interest in China's aid and investment in the Pacific Islands region and the alleged security threat this poses (Smith 2018). It is interesting to see how this attention has transformed to be characterised in negative terms, as if aid from other donors has not also created a dependency syndrome amongst Pacific Island countries. These security threats are largely manufactured, fuelled-up fears led mainly by some in the Australian media (Wroe 2018) and think tanks (Dobell 2018), stoking fear amongst the Australian, New Zealand and broader Western security axis. This fear is not for the safety and security of the people of the Pacific Islands. The Pacific Islands are important from a traditional security perspective because they provide a buffer against a forward attack on Australia and New Zealand, as well as because Chinese engagement in the Pacific Islands region is increasingly viewed as a threat to historical Western dominance. This powerplay between the Western axis and China in recent years has resulted in increased support to the Pacific Islands region, most notably in infrastructure and military aid. All of the Western Axis countries have increased their engagement; even Great Britain has reopened diplomatic posts in Tonga, Vanuatu and Samoa (Bourke 2018). Australia, New Zealand, France and the US have all increased their aid and propped up their security apparatus, arguably increasing the aid dependency of Pacific Island countries at a time when they need to reduce their dependency and become more self-reliant in terms of their economic and social wellbeing.

It was against this backdrop that Solomon Islands confronted the choice between Taiwan and China. Like other Pacific Island countries, Solomon Islands is seeking a sense of purpose, wanting to become more selfreliant, especially after the departure of the Regional Assistance Mission to Solomon Islands (RAMSI), a regional intervention that was deployed from mid-2003 to 2017 following civil unrest in Solomon Islands that led to the near collapse of the state, the deterioration of the country's economy and the death of about 200 people (Hameiri 2009; Moore 2004). The country is confronted with security issues born not out of external threats from war or terrorism, but from internal threats ranging from a lack of employment opportunities to a lack of entrepreneurial skills that would allow people to participate effectively in the global trading system; the loss of biodiversity and ecosystems through changes in the climate; the loss of habitat and arable land from rising sea levels; and the devastating health effects of noncommunicable diseases brought by 
changes in diet and lifestyle. These are some of the challenges Solomon Islands faces, which it has to navigate in its relations with other countries, including China.

In addition to these issues is, as mentioned previously, the increasing population of new Chinese migrants who dominate the retail sector, especially in the urban areas. The only provinces that have so far been able to withstand the wave of Chinese migration and the takeover of their retail sector are Choiseul, Temotu, Isabel and Makira/Ulawa. It is not clear whether they will be able to withstand pressure from other growing businesses, especially in the mining sector, which might become the dominant natural resource sector as the forestry industry winds down.

While the wave of new Chinese migrants seeking to establish retail shops may be limited to urban centres, the presence of Malaysian Chineseowned logging companies is widespread throughout the country. To that extent, the level of integration between ethnic Chinese-owned businesses and the Solomon Islands society is almost complete, with the exception of remote places such as Tikopia and Anuta in the east. The major provinces of Guadalcanal, Malaita and Western have been unable to withstand the migration of Chinese nationals who have established retail shops and dominated the retail sector. In Honiara, these migrants-largely from Guangdong province (Smith 2012) - have already taken most, if not all, of the capital's commercial sites. This migration is enabled by a combination of domestic factors, most notably the corruption of government officials; the corrosion of state institutions, particularly the departments of immigration and labour; and the crowding out of Solomon Islanders from the financial sector, which has encouraged them to sell their land to new arrivals because they have not been able to secure funds to develop it. While the switch in diplomatic relations from Taiwan to China was determined largely by trade and investments, Solomon Islands needs to carefully consider the underlying contributing issues.

Now that Solomon Islands has made the switch, there is a need to learn from the Pacific Islands countries that appear to be struggling with the debts they owe to China. Solomon Islands needs to reassess its governance capacities to see how it can best manage this new relationship. As it is, Solomon Islands does not have the wherewithal to manage the tradeoffs that will be required to handle the links between a sudden influx of no-strings-attached development finance and the further opening up of its natural resources. Since the departure of RAMSI, and despite the 
exorbitant investments it made to the machinery of government and the control of public finances, Solomon Islands public service and institutions have become weaker and tainted by a level of corruption never before seen. The government is therefore in a weak position to manage this new relationship that will require trade-offs for grants and loans. Currently, the Solomon Islands Government is unable to properly manage its natural resources sector effectively. Consequently, having state-backed Chinese companies exploiting the mineral, forestry and fisheries resources of Solomon Islands with in-country support from a new embassy could prove disastrous for the people of Solomon Islands. In order to save the country from itself and possible exploitation, Solomon Islands should carefully consider how it will manage this new diplomatic relationship.

\section{Taiwan-Solomon Islands relations: An unstable ship?}

Prior to the switch, Solomon Islands Government officials typically described their country's relationship with Taiwan as strong. I would argue, however, that it was an uneasy and unstable relationship at best. Invariably lurking in the background was China, threatening to lure Solomon Islands to switch. This was a factor that some government officials and politicians in Solomon Islands took advantage of. While the Solomon Islands Government had not officially considered a switch prior to 2019, some government officials and politicians had at least considered it, especially as China's trade and investments increased. For example, former prime minister Gordon Darcy Lilo, who contested the April 2019 election, commented that 'sooner or later, when we see our country hasn't been able to grow out of this relationship [with Taiwan], we are at liberty to review our relations and to explore other avenues' (Greenfield and Westbrook 2019). Taiwan and China have often taken advantage of their respective vulnerabilities at the highest political level. It was initially the government of Taiwan that propped up the discretionary fundsthe Rural Constituency Development Fund (RCDF) — controlled by politicians. These funds have transformed Solomon Islands' political landscape by shifting the political power base away from voters and government bureaucracy and into the hands of politicians. Though there has been a decline in the level of Taiwan's contribution to the RCDF in recent years to around 20 per cent, and the Solomon Island Government's contribution has risen sharply, there is still a perception 
amongst urban elites that Taiwan has contributed to their funding and created a system that entrenches the power of politicians. The RCDF has caused controversy, especially amongst the urban elite and the Solomon Islands diaspora, because it is viewed as supporting political corruption and giving incumbent MPs undue advantages in elections. Regardless of the accuracy of this view, it has coloured people's views of Taiwan.

The relationship between Taiwan and Solomon Islands is not one based on mutual trust and goodwill, but one Solomon Islands politicians have used to gain political mileage, often at the expense of good governance and the social and economic wellbeing of the people. Solomon Islands politicians have played on this relationship and used it to support their political base. Criticisms of the RCDF have been elitist, urban-based and largely focused on the ineffectiveness of the fund as a mechanism for rural development. This is particularly important given the fact that the RCFP represents around one-third of the government's development budget and between 10 and 15 per cent of overall budget outlays (Wiltshire and Batley 2018). However, it is also important to note that the RCDF has helped some people and served its purpose. But in a Least Developed Country like Solomon Islands, there are better ways of ensuring a more equitable delivery of health, education and other social services. The government of Taiwan has been complicit in the way the national parliamentarians have undermined the budgetary and development processes. This perception is borne out by Taiwan's initial support for the RCDF, and it is felt that Taiwan is always ready to help Solomon Islands at any costs.

However, beyond the urban centres, most rural people have no particular view of Taiwan's support for the RCDF and are probably grateful for whatever materials they have received through Taiwan's support. Some of the most popular Taiwanese projects channelled through the RCDF are the rural solar lighting programs, administered by the MPs. There has been no evaluation of the ways in which solar lighting projects have impacted Solomon Islanders' livelihoods. The quality of the products used, however, is poor, and most of the solar panels, batteries and lights do not have long life spans. But most people who receive these projects do not care about the quality of the solar panels or batteries and are only too happy to receive a free gift. This dependency mentality cultivated through the RDCF and the wasteful allocation of limited resources has led to criticism of Taiwan's laissez-faire approach to aid in Solomon Islands. 
No other country with which Solomon Islands has diplomatic relation has generated this level of controversy. Once again, only educated elites have expressed disquiet about the way Taiwanese aid supports a mechanism that is, in effect, a slush fund for national parliamentarians. Consequently, the widespread view among the general public in Taiwan that their aid to Pacific Island nations is wasted (Huang 2017) seems well-founded in Solomon Islands. The relationship between Taiwan and Solomon Islands has changed over the years; while it has been based on mutual trust, respect and support for Taiwan's independence, the emergence of the RCDF has changed the nature of the relationship.

In 1983, four years after gaining independence, when Solomon Islands chose to establish relations with Taiwan, the world was very different. The Cold War was still the major international influence that polarised the world between capitalism and communism, and China was only starting its 30-year journey of economic transition. Cold War dynamics drove the Solomon Islands Government to establish relations with Taiwan. They were attracted to the idea that Taiwan was a democratic country and not part of communist China, even though Taiwan no longer represented China at the United Nations. The international order at that time was clearly demarcated between the West, led by the US, and the communist countries, led by the Soviet Union. China was not the economic force it is now, and Solomon Islands leaders were sensitive to the communist regime in China. Taiwan was more influential and had diplomatic relations with many more countries, so it was not a difficult decision for the Solomon Islands Government to establish diplomatic ties with Taiwan.

Solomon Islands did not immediately establish full diplomatic relations with Taiwan, however, first going through a period during which Taiwan had only consular-level representation. The geopolitical dynamics of the region were tense, as Kiribati had just entered into a fisheries agreement with the Soviet Union. US purse seine fishing vessels were fishing illegally and there were uncertainties over fishing rights. Biddick provides insight into the rivalry between China and Taiwan over Solomon Islands in the early 1980s, and suggests why Solomon Islands established diplomatic ties with Taiwan:

The continuing competition for political influence was particularly evident in the Solomon Islands, as suggested by the contretemps surrounding Prime Minister Alebuas participation in the launching ceremony for a PRC-funded ship in Honiara on October 12, 1988. 
The launching ceremony, just two days after Taiwan's 'Double Ten' celebration in Honiara, symbolised the sister province relationship between China's Guangdong Province and Guadalcanal Province in the Solomon Islands. Guangdong officials had earlier signed a memorandum of understanding for development of a joint venture fishery project, reportedly to include Chinese technical assistance and funding for development of shipbuilding and tuna processing operations in Guadalcanal. Taiwan's ambassador apparently took exception to Alebua's participation in the ship-launching ceremony, and on October 14 the Solomon Islands Ministry of Foreign Affairs and the Taiwan embassy issued a joint statement clarifying that Alebua had participated in a private capacity and reiterating that the two countries remained committed to maintaining 'warm, cordial and friendly' diplomatic relations. In fact, this was but the most recent episode of a protracted triangular drama dating from Alebua's trip to Beijing in 1982 as foreign minister of the Mamaloni government. He had publicly indicated at that time that establishment of diplomatic relations with the PRC was imminent. Instead, the Mamaloni Government ultimately decided to recognise Taipei, apparently in response to inducements offered by the Taiwan authorities (1989:807).

It would not be surprising if Solomon Mamaloni's government did make the decision based on an inducement from Taipei. As chief minister, Mamaloni was forced to resign in 1975 when it was discovered that he agreed to receive funds in return for having his face on Solomon Islands coins. The scandal was known at the time as the Letcher Mint Affair, named for the US company that tried to get a favour in return for an inducement offered to Mamaloni. That a political relationship should be defined by its origins arising from an inducement perhaps reflects the uncertainties that plagued this relationship and the vulnerabilities that can arise from weak states led by corrupt leaders. It is no surprise that the RCDF was initiated when Solomon Mamaloni served as prime minister from 1989 to 1993, and that he asked Taiwan to fund it. Understanding the backdrop of the decision that led to the establishment of political ties with Taiwan helps explain why Taiwan has been willing to support the RCDF and prop up the Solomon Islands political establishment, thereby defining to some extent the nature of the relationship between the two countries, which also influences the contest between China and Taiwan. Graeme Dobell, writing soon after the 2006 Honiara riots, quoted former head of Australia's Department of Foreign Affairs and Trade Stuart Harris, 
who testified to an Australian Senate Foreign Affairs Committee that the diplomatic contest is dangerous because it can easily tear at the structure of a weak Island government:

We found this in the Solomons, where governments are totally disorientated — in fact just about destroyed — by interventions of this kind. You can disorient a government in the Pacific Islands with a very limited amount of money_-just a few bribes to the right people at the top and you have undermined the whole governing system (Dobell 2007:11).

Despite these challenges and negative perceptions about the debilitating effect of the relationship with Taiwan on the quality of governance, it is precisely because of Taiwan's support to the RCDF that the Solomon Islands-Taiwan relationship may be described as healthy and stable at the political level. Indeed, former prime minister Ricky Houenipwela reversed his intent to review the relationship only two weeks after announcing the DAP would do so. However, those who deal closely with Solomon Islands foreign relations were not surprised by the DAP's desire to review the relationship. A Ministry of Foreign Affairs official stated that the Solomon Islands-Taiwan relationship, while strong and enduring, should be broadened to the general community to include people-to-people contacts. ${ }^{2}$ The strength of the relationship was based largely on the contacts Taiwan had with political leaders and government officials, and the various visits and exchanges that often took place at the highest political level reflected this. This observation is surprising as it ignores the support the Taiwan Agriculture Technical Mission gives to farmers, not only through spending time at the farms providing training on vegetable farming, piggery and poultry, but also through workshops it runs in the provinces for agriculture extension officers and farmers. One of the successful aspects of the Solomon Islands-Taiwan relationship is the Taiwan Agriculture Technical Mission, because it aims to both support the government's agricultural assistance to farmers and, more importantly, reach ordinary farmers throughout the country. The success of the program can be seen in the improved quality and variety of vegetables sold in the main market in Honiara, reflecting the training farmers have received.

2 Acting High Commissioner to Australia, 26 January 2019. Canberra. Personal communication. 
Taiwan's relationship with Solomon Islands was shaped around influencing the political leadership and supporting state institutions. There is limited evidence of investment in areas that influence the daily lives of Solomon Islanders in the same way the Chinese have done through Chinese migrants and their stranglehold on the retail sector. Taiwan's development assistance to Solomon Islands has focused around a number of areas, such as support for scholarships for Solomon Islanders to study in Taiwan, including support for the regional scholarship scheme administered by the Pacific Islands Forum Secretariat. In addition to agriculture, they also support the health sector. Their best-known project was the construction of the National Referral Hospital. Though the same level of daily interaction might not be seen as between the Chinese retail shop owners and Solomon Islanders, there are important people-to-people links through the exchange of specialist doctors and visits by Taiwanese health teams in the provinces.

There was generally a lot of goodwill at the highest political level in Solomon Islands towards Taiwan, and there should have been, because the political elites had found a partner who largely had a more-willing ear to lend than other countries, who were less likely to support the political elites. It came as no surprise when, at the 2018 Taiwan Double Ten celebrations, then prime minister Rick Houenipwela said the government 'remained very optimistic about the positive direction which Solomon Islands and Taiwan is heading as is shown in the increasing number of high-level visits made by both government representatives' (Kekea 2018). Other than political convenience, another reason for enduring strong political links was a littleknown fund administered personally by the prime minister. In 2008, while president of the Kossa Football Club (FC), I approached the ambassador of Taiwan in Honiara to see if they were able to assist Kossa FC. As reigning club champions, they were to represent Solomon Islands in the FIFA Oceania Football Confederation Club championship. The ambassador told me that they did not have any funds he had discretion over, but advised me to approach then prime minister Dr Derek Sikua. He said there was a fund only the prime minister could authorise the use of, through which they would be able assist Kossa. Few people knew of the existence of this fund. The ambassador said the funds could be released by Taiwan only if a request was personally signed by the prime minister. The next day, I saw Dr Sikua and asked if he could make a request to the government of Taiwan to use this fund, as our club was representing Solomon Islands and our pride and national interest was at stake. He liaised with the secretary to the prime minister's office, who at the time was Jeremiah Manele. I drafted 
the required letter and the prime minister duly signed it. The request was to fund the team to play in Vanuatu and Fiji in the last leg of the championship, which Kossa FC eventually lost in the final to Waitakere FC of New Zealand. US\$30,000 was released by the government of Taiwan to the Solomon Islands Football Federation to enable Kossa to meet all its travel expenses. I was surprised by the existence of this fund, as I had no idea there was such a fund that could be used at the discretion of the prime minister. This illustrates the comfortable relationship between Taiwan and the political leaders of Solomon Islands. It is not hard to imagine that this fund could have been used to persuade MPs against a switch to China. No other country with whom Solomon Islands has diplomatic relations would agree to provide such funds. This supports the view that Taiwan's aid fuelled bad governance.

There is also a regional dimension to Solomon Islands' relationship with Taiwan. The six Pacific Island countries that previously had relations with Taiwan would hold the Taiwan-Pacific Islands Forum Dialogue on the margins of Pacific Islands Forum leaders meetings. One of the features of these dialogues was the announcement of projects to be funded by Taiwan. Representatives from the various regional agencies who submitted bids through the Pacific Islands Forum Secretariat took a keen interest in the dialogue. Taiwan's overseas development assistance (ODA) to the region, including Solomon Islands, between 2011 and 2016 is provided below (Table 1). Solomon Islands was the largest recipient of funding support from Taiwan, which was the fourth largest donor to Solomon Islands.

Table 1. Taiwan's support for the Pacific, 2011-16

\begin{tabular}{|l|c|c|c|}
\hline Country & Amount & Donor Ranking & Aid Share \\
\hline Kiribati & $\$ 45,451,985$ & 4 & $10 \%$ \\
\hline Marshall Islands & $\$ 44,591,120$ & 3 & $10 \%$ \\
\hline Nauru & $\$ 4,111,000$ & 5 & $2 \%$ \\
\hline Palau & $\$ 3,590,000$ & 6 & $2 \%$ \\
\hline Solomon Islands & $\$ 76,387,935$ & 4 & $5 \%$ \\
\hline Tuvalu & $\$ 73,394$ & 20 & $0.04 \%$ \\
\hline Total & $\$ 174,205,436$ & 5 & $6 \%$ \\
\hline
\end{tabular}

Note: Despite having a high donor ranking, aid share remains relatively low because aid in the Pacific is often heavily concentrated in a select number of donors, usually either Australia or the US, or Japan in the case of Palau.

Source: Dayant and Pryke (2018). 
An important feature of the relationship between Solomon Islands and Taiwan was that during the ethnic tensions in Solomon Islands between 1998 and 2003, it was Taiwan's ODA that kept Solomon Islands foreign reserves intact. Atkinson states that:

as the crisis developed and international donors began withholding aid due to serious governmental irregularities, the Solomon Islands' leadership turned to Taiwan to meet the spiraling compensation demands of the conflicting parties. The Chen Shui-bian Government, elected in March 2000, aimed to improve Taiwan's tarnished donor image, but was unable to resist being pulled deeper into the crisis. In June 2001, Taiwan's stateowned EXIM Bank agreed to a US\$25 million loan after the Solomon Islands Government threatened to switch diplomatic recognition to China. The package was used to finance hundreds of payouts routed through Allan Kemakeza's Ministry of National Unity, Reconciliation and Peace. Kemakeza himself was at the top of the list, and was later sacked for embezzlement over the issue. Parliament nonetheless elected Kemakeza prime minister following the 5 December 2001 elections. The final tranche of the EXIM loan arrived in September 2002, and as the money ran out the crisis reached its nadir, with Cabinet and the Finance Ministry invaded by armed men, including police, demanding money (2009:50).

In an analysis of Taiwan's overall approach to the Pacific, Michael Nguyen and Jonathan Pryke (2018) argued that Taiwan attempted to offset China's appeal by working with Pacific partners in different ways. It recognised that it could not exceed the monetary value of Chinese aid and thus identified areas of Pacific development where its smaller contributions could still be effective. Nguyen and Pryke contend that Taiwan's 'projects targeting sectors such as agriculture, health and industry ... emphasise Taiwan's advantage: people-to-people relationships'. An example is Taiwan's horticultural projects. These sought to increase the sustainable productive capacity of local populations through training workshops, internships and extended foreign missions by envoys. Increased exposure of local Pacific communities to Taiwanese experts was a key element driving Taiwanese aid. The working relationships that arose created goodwill and fealty that can only come about through prolonged cooperation. I have argued previously that this aspect of the relationship was highly visible and successful. 
Observers invariably contextualise Taiwan's political relations in terms of the tussle it has with China and compare the aid both countries give to the Pacific Islands region. In an analysis of the impact of Taiwan's aid to the region, Jonathan Pryke and Alexander Dayant (2018) said this of its assistance to Solomon Islands:

That isn't to say Taiwan's engagement has been unnoticed. It has significantly impacted lives of those in the Pacific, in some cases profoundly. The clearest case of this is in Solomon Islands. The primary mechanism for Taiwanese support to Solomon Islands comes in the form of supporting 'Constituent Development Funds'-a discretionary fund that is allotted to each of the country's 50 MPs for investing in their electorates (with minimal oversight). Taiwan has provided close to $\$ 90$ million to these funds between 2011 and 2018. Solomon Island politicians like these funds so much that they have allocated around one-third of the development budget, or between 10 and 15 per cent of the total budget, to these funds. In this regard, Taiwan's aid program has contributed to profoundly changing, and perhaps undermining, public financial management in its largest supporter in the Pacific. (For a more nuanced discussion on the challenges of being an MP in Solomon Islands, take a look at now Prime Minister Rick Hou's reflections for the Department of Pacific Affairs in 2016).

Underscoring the fickleness of the Solomon Islands-Taiwan relationship, in 2018 the then prime minister Rick Houenipwela 'hailed' Solomon Islands bilateral relationship with Taiwan as 'growing steadily' (Radio New Zealand 2018). Even though a number of other countries had switched relations from Taipei to Beijing, prime minister Houenipwela said 'his government was committed to maintaining and further consolidating relations ... [and that] Taiwanese funding had helped with agricultural programmes, medical assistance and the fight against climate change'.

Solomon Islanders as well as outside observers have always questioned the future of Solomon Islands relations with Taiwan. Australian diplomat James Batley (2018), for example, observed that:

Taiwan faces a number of challenges in shoring up its links with Solomon Islands. For the past couple of decades, Taiwan has invested heavily in Solomon Islands' political elite through its support for the notorious 'constituency development funds', which is the discretionary funds provided for members of parliament to spend in their own constituencies. 
In some respects, though, Taiwan has become a victim of its own success in supporting these schemes: as the size of these programs has grown, the Solomon Islands Government itself has picked up ever more of the tab, to the point where Taiwan is now funding under 20 per cent of the total, down from 50 per cent less than 10 years ago. So the relative importance and impact of Taiwan's contribution has shrunk.

Even more worrying from Taiwan's point of view, China is far and away Solomon Islands' largest export market. The most recent figures (for 2016) from the Department of Foreign Affairs and Trade in Australia state that over 62 per cent of Solomons' exports go to China. (This is virtually all logs.) By contrast, Taiwan takes around only one per cent of exports from Solomon Islands.

Such a level of economic dependence on China leaves Solomon Islands highly vulnerable to economic pressure-should this be exercised. Senior Solomon Islanders will be aware of claims made earlier this year that Palau, another of Taiwan's Pacific allies, has been the victim of economic pressure with China essentially turning off the tap of a lucrative flow of Chinese tourists to the small northern Pacific country.

Given the importance of Solomon Islands' trade with China, in the past few years Taiwan's relations with Solomon Islands went through periodic waves of unease, with visits by government officials and politicians to China. I have described how Solomon Islands politicians view their relationship with Taiwan, to some extent taking advantage of Taiwan's vulnerabilities. In return for flexible funding arrangements, and perhaps the discretionary funds the prime minister has access to, Solomon Islands has always used its statement to the annual general meeting of the United Nations General Assembly to call for the reinstatement of Taiwan as a full member of the United Nations and its various organs.

There is never going to be any support for Taiwan's reinstatement in the United Nations. But this never stopped Solomon Islands from staging the theatre of appeals to the international community to allow Taiwan to rejoin. This was a small trade-off for the aid that was administered through the prime minister's office. It gave Taiwanese officials a sense of lien, a right of access other diplomatic missions do not have. My conversations with senior officials indicate that staff at the Taiwanese embassy felt they could meet with the permanent secretary and Minister of Foreign Affairs at any time, even though they were not at the ministerial level and 
protocol dictates they should meet with relevant officers in the Ministry of Foreign Affairs before accessing more senior staff. They were also the only diplomatic mission in Honiara that had the keys to the VIP lounge at the airport and could use it without necessarily going through the Protocol Department of the Ministry of Foreign Affairs. This shows that money can buy access.

\section{The China factor}

Hovering in the background of the Solomon Islands-Taiwan relations was China. This is the unavoidable, and almost inconvenient, truth of the relations Taiwan enjoys with any country, including Solomon Islands, and perhaps explains why the number of countries that have diplomatic relations with Taiwan is heading rapidly towards single figures. China is a global economic and political power and Solomon Islands' largest trading partner. These are important considerations and must have been playing in the minds of current and aspiring MPs. However, there are broader policy issues the government must canvass when viewing its relations, as trade is only one factor. Table 2 shows the trade data for Solomon Islands. It is evident that China is an important actor in the economic affairs and interests of Solomon Islands, while Taiwan does not make the top 10.

Table 2. Top 10 export destinations for Solomon Islands

\begin{tabular}{|l|l|}
\hline Country & Export US\$ \\
\hline China & $\$ 325,830,017$ \\
\hline Italy & $\$ 38,695,793$ \\
\hline Switzerland & $\$ 19,335,916$ \\
\hline India & $\$ 18,192,934$ \\
\hline Philippines & $\$ 17,583,591$ \\
\hline Netherlands & $\$ 15,005,260$ \\
\hline Malaysia & $\$ 7,553,025$ \\
\hline Hong Kong & $\$ 6,436,486$ \\
\hline Thailand & $\$ 6,331,429$ \\
\hline Vietnam & $\$ 4,920,341$ \\
\hline
\end{tabular}

Source: Global Edge (2019). 
Tables 3 and 4 show the bilateral trade between Solomon Islands and Taiwan. China's trade with Solomon Islands dwarfs that of Taiwan, reflecting the strong commercial ties Solomon Islands has with China.

Table 3. Solomon Islands-China bilateral trade (SB\$ million)

\begin{tabular}{|l|c|c|c|c|c|c|}
\hline & $\mathbf{2 0 1 3}$ & $\mathbf{2 0 1 4}$ & $\mathbf{2 0 1 5}$ & $\mathbf{2 0 1 6}$ & $\mathbf{2 0 1 7}$ & Average \\
\hline Balance & 1,344 & 1,502 & 1,451 & 1,634 & 2,000 & 1,586 \\
\hline Exports & 1,600 & 1,944 & 1,842 & 2,169 & 2,566 & 2,024 \\
\hline Imports & 256 & 441 & 390 & 535 & 566 & 438 \\
\hline
\end{tabular}

Source: Central Bank of Solomon Islands (2019).

Table 4. Solomon Islands-Taiwan bilateral trade (SB\$ million)

\begin{tabular}{|l|c|c|c|c|c|c|}
\hline & $\mathbf{2 0 1 3}$ & $\mathbf{2 0 1 4}$ & $\mathbf{2 0 1 5}$ & $\mathbf{2 0 1 6}$ & $\mathbf{2 0 1 7}$ & Average \\
\hline Balance & 51 & 26 & 30 & 28 & 33 & 33 \\
\hline Exports & 95 & 40 & 45 & 53 & 59 & 58 \\
\hline Imports & 44 & 14 & 16 & 25 & 27 & 25 \\
\hline
\end{tabular}

Source: Central Bank of Solomon Islands (2019).

Table 5 shows how imports from China compare with those from Taiwan and the rest of the world from 2007 to 2017. Over a 10-year period, imports from China far surpassed those from Taiwan, underlining the importance of China to the Solomon Islands economy.

Table 5. Percentage of Solomon Islands imports from China and Taiwan

\begin{tabular}{|l|c|c|c|c|c|c|c|c|c|c|c|}
\hline & $\mathbf{2 0 1 7}$ & $\mathbf{2 0 1 6}$ & $\mathbf{2 0 1 5}$ & $\mathbf{2 0 1 4}$ & $\mathbf{2 0 1 3}$ & $\mathbf{2 0 1 2}$ & $\mathbf{2 0 1 1}$ & $\mathbf{2 0 1 0}$ & $\mathbf{2 0 0 9}$ & $\mathbf{2 0 0 8}$ & $\mathbf{2 0 0 7}$ \\
\hline China & $13 \%$ & $15 \%$ & $11 \%$ & $12 \%$ & $1 \%$ & $8 \%$ & $11 \%$ & $15 \%$ & $10 \%$ & $6 \%$ & $5 \%$ \\
\hline Taiwan & $1 \%$ & $1 \%$ & $0 \%$ & $0 \%$ & $1 \%$ & $1 \%$ & $1 \%$ & $0 \%$ & $1 \%$ & $0 \%$ & $1 \%$ \\
\hline $\begin{array}{l}\text { Rest of the } \\
\text { world }\end{array}$ & $87 \%$ & $85 \%$ & $89 \%$ & $88 \%$ & $98 \%$ & $91 \%$ & $89 \%$ & $85 \%$ & $89 \%$ & $94 \%$ & $94 \%$ \\
\hline
\end{tabular}

Source: Central Bank of Solomon Islands (2019).

Table 6 illustrates the percentages of Solomon Islands' exports and imports with its major trading partners. Taiwan does not feature in the statistics, but China features quite prominently, once again underscoring the importance of China to the Solomon Islands economy. 
Table 6. Solomon Islands major trading partners, exports and imports, 2013-17

\begin{tabular}{|l|c|l|}
\hline & $\begin{array}{c}\text { \% of } \\
\text { exports* }\end{array}$ & Commodity \\
\hline China & 58 & Logs \\
\hline Australia & 7 & Timber, mixed \\
\hline Italy & 7 & Fish \\
\hline UK & 5 & Palm oil \\
\hline Philippines & 3 & Copra \\
\hline Total SB\$m & $\mathbf{3 , 5 0 6}$ & \\
\hline
\end{tabular}

\begin{tabular}{|l|c|l|}
\hline & $\begin{array}{c}\text { \% of } \\
\text { imports* }\end{array}$ & Items \\
\hline Australia & 30 & Food, mixed \\
\hline Singapore & 14 & Fuel \\
\hline China & 11 & $\begin{array}{l}\text { Household, } \\
\text { mixed }\end{array}$ \\
\hline Japan & 8 & $\begin{array}{l}\text { Machines, } \\
\text { cars }\end{array}$ \\
\hline $\begin{array}{l}\text { New } \\
\text { Zealand }\end{array}$ & 7 & Food, mixed \\
\hline Total SB\$m & $\mathbf{3 , 8 6 4}$ & \\
\hline
\end{tabular}

* 5 -year average.

Source: Central Bank of Solomon Islands (2019).

Three aspects pertaining to China are important to Solomon Islands. The first is the volume of trade and the size of the trade surplus with China in contrast to the large trade deficits run with Australia and Singapore (the main source of fuel imports). However, most, if not all, of the exports to China are round logs from unsustainable commercial logging. Foreign logging companies that control the industry have been responsible for the corrosion of good governance and extremely poor environmental practices for logging. There is a lot of controversy surrounding this industry and China's demand for round logs is exacerbating the deforestation of Solomon Islands (Global Witness 2018). The bribery of officials, politicians and villagers by the logging industry has led to a culture of corruption that is pervasive throughout Solomon Islands society (Aqorau 2008).

Solomon Islands' trade surplus with China, impressive as it is, remains tied to an industry that has undermined good governance and degraded the natural environment. Despite the RAMSI intervention, corruption by government officials has become more pervasive. Parliament passed anticorruption legislation in 2018 , which provides a framework to address the problem. However, is not clear if the government has the resources to make the legislation effective. According to Transparency International, Solomon Islands dropped two points in the 2019 Corruption Perceptions Index, from 44 points in 2018 to 42 points (Radio New Zealand 2020). The weak state institutions that characterise the Solomon Islands Government have thus far been incapable of addressing the impact of the exploitation of Solomon Islands forests. Mining represents the extraction 
of another natural resource that Chinese businesses have shown an interest in, and, like the forestry sector, the mining sector has suffered from weak compliance stemming from weak state institutions.

The second factor is the migration of new Chinese, who now dominate the retail sector. Most, if not all, the prime retail sites in Honiara are owned by these new arrivals, creating increasing levels of animosity towards them from locals. They are known to bribe their way through government offices to secure licences, work and residential permits and planning permissions, further exacerbating the level of corrosion in the public service. Despite the Honiara riots in 2006, which saw many of the new Chinese businesses burnt and looted, their presence has increased and expanded to the provinces as well. The dominance of Chinese businesses in the retail sector has firmly entrenched Chinese interests, and arguably integrates Solomon Islands' economy, jobs, trade and businesses with China. In contrast, Taiwan's relationship with Solomon Islands is not integrated across the business sector.

To provide a long-term perspective on the new Chinese arrivals, I interviewed John Leong, a Chinese Solomon Islander from Malaita. His father Leong Kee married a woman from Langalanga in Malaita, and he grew up knowing both his mother's Solomon Islands culture and his father's Chinese culture. When he was small, he was sent to stay with his grandmother in Hong Kong and they would visit their relatives in Guangdong in mainland China. He returned to Solomon Islands after completing secondary schooling in Hong Kong. He explained that many of the new Chinese immigrants were not interested in investing in the country to help the Solomon Islands economy, but were really there to do business for themselves and then move to the US, Australia or New Zealand. Most have no particularly strong feelings for the country, unlike many older Chinese who initially immigrated to Solomon Islands, settled down and have family who have taken over their shops. Most, if not all, of the newly arrived Chinese retain strong links back to their homeland and families.

The third factor is Guadalcanal Province's sister relationship with Guangdong Province in China, which has allowed provincial government officials and politicians to engage with the Chinese in a deeper and more integrated way than is the case with Taiwan. The Overseas Chinese Affairs Office of Guangdong Province, now subsumed by the United Front Work Department, is responsible for the Chinese community in 
Solomon Islands (this includes all people of Chinese descent, even those from Taiwan and Hong Kong-including John Leong). For Solomon Islanders, the most important factor is their public presence in the shops, on the road driving vehicles, in the rural areas working in the logging camps and in the warehouses. They have a noticeable presence in the community that allows Solomon Islanders to interact with them on a daily basis. Even if they have brought some practices that have corroded good governance within the public sector, their involvement in the community is providing employment opportunities for Solomon Islanders. Moreover, the corruption occurs because local conditions encourage it.

In an article published in the Solomon Star on 28 January 2019, former immigration officer Richard Mana claimed that he had witnessed extensive corruption in the government system. He said:

Between 2009 and 2011, three Asian girls were deported after they were caught engaging in an underground prostitution ring. 'These girls were brought in by those running the ring and entered the country on tourist visas', Mana said. He said the girls were then used to serve customers of the prostitution ring, which operates from a well-known commercial establishment in town. 'There were locals involved in the organisation to bring the girls over. They are those in authority who I believe were paid to assist organisers of the ring'. He also claimed that a lot of foreigners have overstayed their visas. Mana said that in cases like this, they should be fined but due to leniency from authorities, the country loses muchneeded revenue. He said he was also aware of top public officers who accepted gifts of cars from foreign business people in return for their favours when it comes to matters like visas and licenses. Mana said that as a junior officer, they were left at the mercy of their bosses, who dictated decisions on issues from the top. He stated government officers were easy prey because they worked for very small salaries so it is easy for them to be manipulated. He further claimed that junior officers knew what the bosses are doing but they were powerless to do anything. 'An example is the issuing of work permits to foreigners just within days after arrival. Some of these foreigners, especially those working in the logging industry, should not be issued with work permits because they are not qualified. Yet they were given work permits to go and drive log trucks, operate chainsaws, and do other jobs that could be easily filled locally. That's the kind of corruption going on within our system' (Babasiana 2019). 
Interactions with Chinese and other foreign nationals have introduced a level of corrosion to good governance and the government machinery, highlighted by the former immigration officer, that should also have some bearing on the way in which Solomon Islands will be able to conduct its relations in the future. But the interactions with the new Chinese provide an economic pathway for Solomon Islanders to learn from the entrepreneurialism of the Chinese. This is perhaps something the Solomon Islands Government can do through a program of affirmative support for indigenous Solomon Islanders to participate in business, not as bystanders but as drivers. It is not hard to imagine a policy of affirmative support for indigenous Solomon Islanders through a program that guarantees loans for them to construct buildings, which they can then rent to the Chinese. There is no reason for indigenous Solomon Islanders to sell their land because they are unable to develop it because they lack the capital to build retail space. This is one path the Solomon Islands Government can pursue, rather than complaining about the influx of new Chinese migrants who are buying land from indigenous Solomon Islanders and developing it for their own benefit.

\section{The China switch}

Following Solomon Islands' national general election in April 2019, Manasseh Sogavare was elected prime minister, making it his fourth stint as the country's leader. He subsequently formed a coalition government dubbed the Democratic Coalition Government for Advancement. One of the new government's most prominent policies was the review of the country's relationship with Taiwan and the exploration of the possibility of switching relations to China. Discussions about the China switch, especially amongst MPs and their associates, started prior to the election and intensified following it. Not long after his election as prime minister, and in referring to Solomon Islands' relationship with Taiwan, Sogavare acknowledged that 'we are under a lot of pressure to rethink this relationship' (Dziedzic 2019). This was fanned largely by the anticipation that diplomatic relations with China would attract greater financial assistance, particularly for infrastructure development and the RCDF.

In Solomon Islands, there were mixed reactions to the proposal. Many entrepreneurs of Chinese descent supported the switch. This included people like Tommy Chan, a former MP and well-known businessman, and 
owner of the Honiara Hotel. For him and other Chinese and indigenous Solomon Islander entrepreneurs, diplomatic relations with China could potentially improve trade and investment opportunities, which would be good for business. This was a sentiment held by many politicians and their supporters. For example, in an interview with $\mathrm{ABC}$ News, former prime minister Gordon Darcy Lilo asked:

What is wrong for this country to consider the opportunities that can come out from a China that is a reformed China and a China that can offer a better economic opportunity? (Dzeidzic 2019)

This was partly a reaction to concerns expressed by traditional partners such as Australia, New Zealand and the US. While acknowledging that this was a sovereign decision for Solomon Islands, there was disquiet in Canberra about the switch. In June 2019, following his election as prime minister of Australia, Scott Morrison's first official visit was to Honiara, where he pledged AU\$250 million worth of Australian assistance to Solomon Islands (The Guardian 2019). Even the US weighed in, offering to assist Solomon Islands in light of growing Chinese influence. When the Solomon Islands Government cut ties with Taiwan, the US subsequently reassessed its proposed aid to the country (Reuters 2019).

Other Solomon Islanders were opposed to the proposal largely due to concerns about Chinese domination of businesses; allegations that Chinese citizens and their money have corrupted Solomon Islands politics and public service; and fears that Chinese Government assistance could lead to increasing national debts. There were also concerns about the lack of consultation in the decision-making process on the matter. Then opposition leader Matthew Wale, for example, accused the Sogavare Government of rushing the issue and argued that:

there's been no discussion at all about what are our national interests. What are we trying to achieve? What are we looking for? Are we just looking for more money? At the moment it seems that's the driving force (Dziedzic 2019).

For many Solomon Islanders, their opposition to the switch was influenced by the fact that their encounters with China had mostly been with Chinese shopkeepers, loggers, fishermen, etc. As discussed previously, these Chinese were largely seen as unscrupulous individuals with a no-care attitude towards the place and its people. That is the lens through which most Solomon Islanders see, interact with and understand China. 
While public debates were still ongoing and the Foreign Relations Committee still carrying out its assessment, the Solomon Islands Government in September 2019 severed its 36-year diplomatic relations with Taiwan. The decision was based on the report of the bipartisan task force, which recommended the switch. The issue was never debated in parliament. In fact, the report of the Foreign Relations Committee, which was released in November 2019, criticised the switch and recommended that the government 'should deepen its relationship with the Republic of China (Taiwan) instead of severing existing ties' (National Parliament of Solomon Islands Foreign Relations Committee 2019:11). It was obvious, however, that most MPs wanted to see a deeper engagement in their foreign relations and were therefore attracted by the potential for increased Chinese investments. They had seen and were lured by the Chinese investments in the other Pacific Island countries they have diplomatic relations with. It was also obvious that China already had a strong informal presence in the country through its citizens, its trade and ongoing investments from Chinese-owned businesses. The potential for greater investment and trade was a major driver to switch to China. It was anticipated that China would bring additional resources to facilitate much-needed infrastructure to foster rural development so that Solomon Islands' untapped natural resources, including its wealth in minerals, could be explored and developed.

But while the relationship with China is sealed, Beijing has not yet won over the entire country. As Zhang and Futaiasi point out:
Although China presently has an upper hand in the diplomatic wrestle with Taiwan in Solomon Islands, the controversies surrounding the switch suggests it is too early for Beijing to claim victory. The challenges are serious, whether they are objections from politicians or grassroots in Solomon Islands (2020:5).

The most vocal challenge to the switch was from the Malaita provincial government. In October 2019, a Malaita Communiqué was published, 'stating that the province "rejects the Chinese Communist Party-CCP and its formal systems based on atheist ideology", and pledged to prevent "willful and exploitative investors"' (ibid.). More concerns emerged when, a month after the switch, the government of the Central Province signed an agreement with China Sam Enterprise Group Ltd for a long-term lease of the island of Tulagi. The agreement was later nullified by the attorney general, but it illustrated how Chinese companies could bypass 
the national government and target subnational governments, which 'are a softer target for influence operations, being subject to less media oversight and scrutiny by civil society' (Foukona and Smith 2019).

In this discussion, it is important to consider what Solomon Islands will likely lose as a result of the switch to China. One of the key features of this new relationship is the potential for flexibility. There is a perception that Taiwan meddles in the political affairs of Solomon Islands by supporting the provision of funds, which politicians use as RCDF. There is also the discretionary fund administered within the Solomon Islands prime minister's office that requires only the prime minister's signature for funds to be provided from Taiwan. However, there are broader policy issues that need to be canvassed. China's global power and outreach is a matter of interest for politicians who want to see the villages in their constituencies connected with roads and electricity. China's Belt and Road Initiative (BRI) offers possibilities that are more difficult to obtain from other donors, though Taiwan recently signed an MOU to provide US\$30 million in 'strategic loans', including support for Solomon Islands to host the 2023 South Pacific Games (Yeh 2019).

Solomon Islands does not have a clear foreign policy framework, and the dilemma of whether or not to switch offered an opportunity to reshape their foreign relations. There were-and still are-concerns about the trade-offs that would be made with its natural resources if Solomon Islands were to receive substantial loans from China. Solomon Islands may be expected to further open its mineral, forestry and fisheries resources to Chinese businesses. There are important lessons to be learned from the impact of the loans taken out by Sri Lanka and Zambia, and how these countries have had to give up the management of state assets to Chinese state-owned enterprises.

As discussed previously, there are elements of the Solomon Islands' relationship with China that are a cause for concern. Arguably, the new Chinese migrants have contributed to the corrosion of the quality of governance in Solomon Islands. Having diplomatic ties with the Chinese Government will enable it to provide consular protection and may put stress on the already weak institutions of the Solomon Islands Government. It is also possible that some of the worst excesses of Chinese businessesat least in Honiara-may be curbed with the arrival of Chinese officials charged with managing the diaspora. Under the BRI, a major priority of China's Ministry of Foreign Affairs is to improve China's international 
image, and new migrants from Guangdong have done little to aid that cause. Previous research indicates a less-than-harmonious relationship between Chinese officials and China's economic migrants to the Solomon Islands (Smith 2012).

\section{Conclusion}

The previously mentioned concerns raise questions about whether or not Solomon Islands rushed into making a decision, and perhaps the timing was not right to switch. Solomon Islands had not fully explored the range of its relationship with Taiwan. Perhaps it should have pushed to have a more structured relationship with Taiwan that extended beyond the narrow confines of the political establishment and government institutions. There should have been more people-to-people interactions and more Taiwanese investments in technology and other areas where jobs can be created for Solomon Islanders.

How the decision was made and the personalities involved cannot be underestimated as a reason for the outcome; there were influential Solomon Islanders working behind the scenes to facilitate the switch to China. Former prime ministers Sir Francis Billy Hilly and Danny Philipp are known to support the switch, as does Sir Tommy Chan. The decision to switch was influenced largely by the business and personal connections of former politicians and certain local Chinese business houses. Though it was a political decision determined by the cabinet, the influence of powerful individuals was paramount. Whilst there was broad public debate about the switch, the decision was ultimately made by a few men: members of caucus and cabinet. There is much to suggest that Solomon Islands is not ready; rather, it should have looked to augment its relations with Taiwan. Now that China has established diplomatic relations with Solomon Islands, Beijing must carefully consider whether or not it wants to contribute to the RCDF or other discretionary funds administered by politicians. Supporting such funds is not the way a normal diplomatic relationship should be conducted. Furthermore, doing so could exacerbate corruption and damage this new relationship between Solomon Islands and China.

Economics and trade are the major factors that influence Solomon Islands foreign policy. With the predicted decline of the logging industry, it is not clear whether this dominant influence will be maintained. They are, 
however, important considerations for now. However, it is respectfully argued that Solomon Islands should be conscious of the cost of Chinese aid. It will not be free. As the example of Papua New Guinea suggests, China's funding support may come at the cost of further opening up natural resources to Chinese companies. Given the poor quality of government-worsened in part by Taiwan's support for the RCDF-and the poor track record of natural resource management, it is argued that the switch will only exacerbate the already weak governance settings in Solomon Islands.

\section{References}

Aqorau, T. 2008. Crisis in Solomon Islands: Foraging for New Directions. In S. Dinnen and S. Firth (eds), Politics and State-Building in Solomon Islands. Canberra: ANU E Press, 246-68. doi.org/10.22459/PSBS.05.2008.10

Atkinson, J. 2009. Big Trouble in Little Chinatown: Australia, Taiwan and the April 2006 Post-Election Riot in Solomon Islands. Pacific Affairs 82(1): 47-65. doi.org/10.5509/200982147

Babasiana, C. 2019. 'Immigration Corrupt': Former Officer Cries Foul. Solomon Star Newspaper, 28 January. www.solomonstarnews.com/index.php/news/ national/item/21302-immigration-corrupt

Batley, J. 2018. Will Solomon Islands Abandon Taiwan? The Interpreter, 4 September. Lowy Institute. www.lowyinstitute.org/the-interpreter/willsolomon-islands-abandon-taiwan

Biddick, T.V. 1989. Diplomatic Rivalry in the South Pacific: The PRC and Taiwan. Asian Survey 29(8):800-15. doi.org/10.1525/as.1989.29.8.01p0298d

Bourke, L. 2018. UK to Open Diplomatic Posts in the Pacific, Citing Security Concerns. The Sydney Morning Herald, 20 April. www.smh.com.au/world/ oceania/uk-to-open-diplomatic-posts-in-the-pacific-citing-security-concerns20180419-p4zan2.html

Central Bank of Solomon Islands (CBSI) 2019. Annual Report 2018. Honiara: CBSI.

Dayant, A. and J. Pryke 2018. How Taiwan Competes with China in the Pacific. The Diplomat, 9 August. thediplomat.com/2018/08/how-taiwan-competeswith-china-in-the-pacificl 
DCGA (Democratic Coalition Government for Advancement) 2019. First 100Days Policy Framework. Honiara: DCGA.

Dobell, G. 2007. China and Taiwan in the South Pacific: Diplomatic Chess versus Pacific Political Rugby. CSCSD Occasional Paper No. 1. Canberra: Centre for the Study of the Chinese Southern Diaspora, ANU. chl-old.anu. edu.au/publications/csds/cscsd_op1_4_chapter_1.pdf

Dobell, G. 2018. Awkward Alarum: China, Vanuatu and Oz. The Strategist, 16 April. Australian Strategic Policy Institute. www.aspistrategist.org.au/ awkward-alarum-china-vanuatu-oz/

Dziedzic, S. 2019. Diplomatic battle underway in the Solomon Islands over China recognition. $A B C$ News, 13 June. www.abc.net.au/radio/programs/am/ diplomatic-battle-underway-in-solomon-islands/11204750

Fanasia, A. 2019. Shaky Ties: Democratic Alliance Party to Review Relationship with Taiwan. Solomon Star, 24 January. www.solomonstarnews.com/index. $\mathrm{php} / \mathrm{news} /$ national/item/21288-shaky-ties

Foukona, J. and G. Smith 2019. Rumblings Along the Federal Fault Line in Solomon Islands. The Interpreter, 21 October. Lowy Institute. www.lowyinstitute.org/theinterpreter/rumblings-along-federal-fault-line-solomon-islands

Global Edge 2019. Solomon Islands: Trade Statistics. www.globaledge.msu.edu/ countries/solomon-islands/tradestats

Global Witness 2018. Paradise Lost: How China Can Help the Solomon Islands Protect its Forests. London: Global Witness. www.globalwitness.org/en/campaigns/ forests/paradise-lost/

Greenfield, C. and T. Westbrook 2019. Solomon Islands Look Beyond Taiwan Alliance as Election Looms. Reuters, 21 March. www.reuters.com/article/uspacific-china-solomonislands/solomon-islands-look-beyond-taiwan-allianceas-election-looms-idUSKCN1R12TR

Hameiri, S. 2009. State Building of Crisis Management? A Critical Analysis of the Social and Political Implications of the Regional Assistance Mission to Solomon Islands. Third World Quarterly 30(1):35-52. doi.org/10.1080/ 01436590802622276

Huang, K-B. 2017. Taiwan and Its South Pacific Allies. The Interpreter, 11 December. Lowy Institute. www.lowyinstitute.org/the-interpreter/taiwanand-its-south-pacific-allies 
Kabutaulaka, T. 2010. Milking the Dragon in Solomon Islands. In T. WesleySmith and E.A. Porter (eds), China in Oceania: Reshaping the Pacific? New York: Berghahn Books, 136-50.

Kekea, G. 2018. PM Hou Congratulates Taiwan on 107th National Day. The Island Sun, 10 October. www.theislandsun.com.sb/pm-hou-congratulatestaiwan-on-107th-national-day/

Maley, P. 2010. If You're Willing to Pay, Nauru Can be Amazingly Accommodating. The Australian, 14 August. www.theaustralian.com.au/national-affairs/if-yourewilling-to-pay-nauru-can-be-amazingly-accommodating/news-story/849d6b8 eafa27aa86b2dcff0d697f559

Moore, C. 2004. Happy Isles in Crisis: The Historical Causes for a Failing State in Solomon Islands, 1998-2004. Canberra: Asia Pacific Press.

National Parliament of Solomon Islands Foreign Relations Committee 2019. Committee Report: Report on the Inquiry into the Question of severing existing ties with the Republic of China (Taiwan). NP-Paper No. 21/2019. Honiara: National Parliament Office.

Nguyen, M. and J. Pryke 2018. Exploring Taiwan's Aid to the Pacific. The Interpreter, 25 September. Lowy Institute. www.lowyinstitute.org/theinterpreter/exploring-taiwan-s-aid-pacific

Radio New Zealand 2018. Solomons' PM Hails Relationship with Taiwan. 15 October. www.radionz.co.nz/international/pacific-news/368662/solomonspm-hails-relationship-with-taiwan

Radio New Zealand 2020. Solomons Drops Two Points in 2019 Corruption Perceptions Index. 27 January. www.rnz.co.nz/international/programmes/ datelinepacific/audio/2018731251/solomons-drops-two-points-in-2019corruption-perceptions-index

Reuters 2019. US Reassessing Aid to Solomon Islands after Taiwan Ties Cut. 19 September. www.reuters.com/article/us-taiwan-diplomacy-usa-solomons/ u-s-reassessing-aid-to-solomon-islands-after-taiwan-ties-cut-idUSKBN 1 W32RL? rid=88752

Smith, G. 2012. Chinese Reactions to Anti-Asian Riots in the Pacific. The Journal of Pacific History 47(1):93-109. doi.org/10.1080/00223344.2011.653482

Smith, G. 2018. Duchesses and Overlords. Inside Story, 18 January. www.inside story.org.au/duchesses-and-overlords/ 
Solomon Islands Government 2019. Report of the Bi-Partisan Task-Force: Review of Solomon Islands Relations with People's Republic of China and Republic of China. Honiara: Office of the Prime Minister and Cabinet.

Solomon Islands Government Monthly Magazine 1982. Relation with China Nearer. Solomon Islands Government Monthly Magazine 1(4):1.

The Guardian 2019. Australia Pledges $\$ 250 \mathrm{~m}$ to Solomon Islands as China’s Influence in Pacific Grows. 3 June. www.theguardian.com/world/2019/jun/03/ australia-pledges-250m-to-solomon-islands-as-chinas-influence-in-pacificgrows

Wiltshire, C. and J. Batley 2018. Research into Constituency Development Funds in Solomon Islands. DPA In Brief 2018/4. openresearch-repository. anu.edu.au/bitstream/1885/141950/1/ib2018_4_wiltshire_and_batley.pdf

Wroe, D. 2018. China Eyes Vanuatu Military Base in Plan with Global Ramifications. The Sydney Morning Herald, 9 April. www.smh.com.au/politics/ federal/china-eyes-vanuatu-military-base-in-plan-with-global-ramifications20180409-p4z8j9.html

Wyeth, G. 2017. The Sovereign Recognition Game: Has Nauru Overplayed Its Hand? The Diplomat, 17 May. thediplomat.com/2017/05/the-sovereignrecognition-game-has-nauru-overplayed-its-hand/

Yeh, J. 2019. Ties with Solomon Islands Stable: Deputy Foreign Minister. Focus Taiwan, 21 March. focustaiwan.tw/news/aipl/201903210007.aspx

Zhang, D. and D.G. Futaiasi 2020. China Has Honiara Onside But Hasn't Yet Won Over Solomon Islands. The Interpreter, 23 January. Lowy Institute. www.lowyinstitute.org/the-interpreter/china-has-honiara-onside-hasn-t-yetwon-over-solomon-islands 
This text is taken from The China Alternative: Changing Regional Order in the Pacific Islands, edited by Graeme Smith and Terence Wesley-Smith, published 2021 by ANU Press, The Australian National University, Canberra, Australia.

doi.org/10.22459/CA.2021.10 